\title{
Pathology and Analysis of Drug Addiction and Provide and Effective Solutions to Prevent it. Case Study: Bonab
}

\author{
Dr.Mohammad Ali Mojallal Chouboglou
}

Assistant professor \& member of the scientific mission Azad university at Bonab. mojallal.2006@yahoo.com

\author{
Elham Tamjidtash \\ Member of Young Researchers' Club in Islamic Azad University at Bonab. \\ tamjidtash@yahoo.com
}

\section{Doi:10.5901/mjss.2013.v4n3p305}

\begin{abstract}
Drug addiction as the most serious social issue of iran has got many aspect s such as sociology ,psychology, law and political. As the social analysts believe, drug addiction is one of the socially complicated issues in the contemporary time and its considered to be base for many social defects and ets. With respect to great importance associated with this topic, this proposal is done whit the main to explore and analyze drug addiction and effective strategies in creating awareness as well as prevention the main questions. This research is an applicational one in purpose and its done in and Sample includes common people, drug addicts and their parents concerned experts in social security force and cultural as well as educational experts. The sample size is 300 and selection is in an random way. Frequency, mean and percentile are used to analyze collected data and ANOVA is used in analyzing differens.A researcher made questioneir is used in data collection process by the scaling from 1 to 5 (as likert scale). Factors, as the analysis of data offers, factors in society and family are considered to be the most effective.Majority believe opium, heroin \& Crystal are the mostly abused drugs in bonab,hoveuer, kerak and hashish are used lesser. Residential houses, parks and public areas are the most common distribution area for these drugs . Majority believe the young age and middle age is the most populated ages for drug addiction. Providing strategies that lead in decreasing demand and supply of narcotics are the most effective ways in prevention last but not the least,as the data analysis offers establishing a counseling center can best lead in to prevention.as ex addicted, cultural experts and social security forces believe, the creative of awareness is the most effective way.
\end{abstract}

Keywords: addictive - drughs -Bonab city.

\section{Introduction}

Drug addiction as the most serious social problem in Iran contains various aspects of sociology, psychology, political and legal. Social analysts believe that narcotic addiction is as a complex social issue of the present era which underlies many of the social injuries and deviations. In other words there is a bilateral relationship between addiction and social issues. On one hand, addiction leads the society to stagnation and decline and on the other hand it is a phenomenon that rooted in social, economic and cultural issues. It decreases individual tendency to the moral and spiritual principles and social values so that the social Pathologists believe that addiction is a household chemical war without borders. The World Health Organization considered it as fundamental issues, narcotics problem, including generation, transmission, distribution and consumption together with the other three global problems: production and stockpiling of weapons of mass destruction, pollution, poverty and social gap which threats seriously social, economic, political and cultural aspects of human life. The necessity of recognition this social problem is understood deeper when people recognize that the phenomenon of addiction is influenced by development of computer and communications technologies, mafia bands and covered hands, and it is so complicate that UN has considered it as one of the organized crimes and issued conventions and different protocols to deal with it. (1961, 1971, 1988 conventions and 1972 amended protocol.) Extensive trade and financial circuit related to narcotic smuggling in the world and the role of regional and global mafia has made considerable this issue (Hashemi, 2004: 17). 
Iran has been passage of narcotic transmission from Afghanistan to Europe due to certain conditions and adjacency to the main centers of narcotics manufacturer and locating in the best and shortest transit way in recent decades. Existing of the fields of narcotics development in Iran and its smuggling which has become an underground trade now, has created the complexity of the current situation and it will become a fundamental crisis in the community.

Regard to importance of this research,it contains comprehensive pathology of narcotics addiction in Bonab and it is suggested the scientific and practical ways for informing and preventing of the spread of this damage.

\section{Theoretical Basics of research variables:}

Addiction $^{1}$ : it means getting used to something (Dehkhoda,1959:2949) The United Nations defined it as: Addiction is acute and chronic poisoning that is harmful to the individual or community and it is caused by the use of natural or industrial drug.

Narcotic addiction has the following three characteristics:

- Feel a strong need to use drug and supplying it in any means possible

- $\quad$ having intense interest to continuous increase of drug consumption amount

- existence of psychological and physical dependence on effects of drug, so that it appeared symptoms of psychological and physical dependence because of lack of access to it (Shahidi, 1996:15)

Addicted2: addicted is a person who uses one or more drugs through different ways such as eating, smoking, injection, and inhalation together and continuously and faces with physical, behavioral problems or both in case of cutting off it (Agabakhshi, 2000:9)

Narcotics: narcotics contains chemicals that cause changes in brain function as creating emotional states, abnormal behavior, anger, or disorder in individual judgment and consciousness ( Mahboubimanesh, 2003:70)

Burned sap: After taking opium, a dark brown and shiny substance is obtained which is called burned latex (Drug Control Headquarters, 2007:8)

Hashish: Hashish is sticky resin of Cannabis ${ }^{3}$ plant which is usually sold in the form of solid cube- shaped pieces.

Heroin: Its chemical name is "diacetylmorphine"and it is derived from Morphine by distillation and is ten times more potent than morphine. It is soft and white or cream and light brown also it doesn't smell but has a bitter taste. (same source: 10)

LSD: LSD is the first drug which placed in hallucinogens group. It is bright or white, odorless crystalline substance with relatively spicy taste and it is often referred to as acid.

LSD is usually sold in the form of tablets, packages and sometimes in liquid form (Abadinski, 2005:181).

Crack: In consumers view, this substance is the prepared food of stimulant drugs. Different types of crack may contain a combination of pure caffeine remains as concentrated caffeine or different amphetamines. Compared to other narcotics, it takes less time to be appeared its effects (same source:152).

Crystal: It is the same as heroin with the more pure and crystalline form and super addictive power. This substance creates symptoms of heroin use with more intensity. Using it slows the motions of the heart as far it leads to the consumer's death (Drug Control Headquarters, 2007:12).

\section{The causes of the tendency to addiction}

Causes of the tendency to addiction are discussed in three aspects: individual, familial and social:

\subsection{Individual causes}

Individual causes of tendency to addiction are more based on theoretical Psychological perspectives.

Knowing the factors that put individuals at risk for addiction, it can be identified people at risk, and to do accurate and effective planning to prevent them addiction.

a. Psychological problems

b. Curiosity

c. Weakness of will

\footnotetext{
${ }^{1}$ Addiction

${ }^{2}$ Addicted

${ }^{3}$ Cannabis
} 


\section{d. Unstable personality}

\subsection{Familial causes}

Family has the main role in children upbringing. A healthy family is family that all of its activities are in accordance with norms and standards of society. The research results indicate that $44 \%$ of the criminals in our society were living in profligate families. Parents neglect to educate their children will lead to dire consequences in the future. Some of the factors that are effective on the tendency to addiction in the family are as follows:

- Lack affection in the family

- Extreme affection

- Discrimination between children

- Limiting children

- Addiction of one of the family member

- Economic welfare of the family

- Family illiteracy or low literacy

- Family poverty

- Parental conflict

\subsection{Social causes}

Because the human beings is naturally social creature and needs to be in society, he/she is faced with a number of social causes which some of them are effective on individual tendency to addiction. Some of the social causes that are influence on tendency to addiction include:

- Easy access to narcotics

- Unemployment and Addiction

- Economic and social inequalities

- the role of the geographic environment and residence

- The role of bad friends

- Industrial development and migration and marginalization

- Weakness of the enforcement of laws and regulations (Queen, 2006:176)

\section{Investigations background}

Fariba Salehi Jonqany(2000) in her research entitled "The Influence of socio - economic factors on addiction" concludes that the majority of addicts have lower socio - economic status. Also there is a significant relationship between parents' education level, income level, isolationism level, the failure rate in life, hope for the future and addiction.

Kothari (2001) in his research titled "Sociology of addiction" in explaining its social origins considers living in deprived areas, extreme poverty, ruined houses, torn apart families and other instabilities as the factors which cause to behavioral deviations and also he believed that addiction has many bad effects on the individual's Familial level. For example, divorce can be as a result of addiction.

In a research, Mansoureh Haj-Husseini \& Mahnaz Akhavan-Tafti(2003) have examined the impact of documentation style on youth tendency rate to addiction. The statistical population of this research was included all youths 28-18 years residing in Yazd in both addicts and non-addicts. It was used the attributional style questionnaire for collecting data. At the end it became clear that the explanation style of the young addicted people for pleasant and unpleasant events is more pessimistic than non-addicted youth.

Bolhari J. (2003) in a study entitled "Assessment of drug use in Iran prisons" is discussed the prevalence of drug use among prisoners in state prisons. This research is a cross-sectional and in the form of quantitative and qualitative study. Comparison of the drug use before and after entering prison indicates significant relationship. About consumers' mental health, $12 / 5 \%$ of individuals, normal and $87 / 5 \%$ were suspected mental disorders. There is a meaningful relationship between drug use in prisons and disorders, somatization, obsession and compulsion, depression and psychosis. Based on the results of this study opium has been most abused substance in prison.

Mahboubi-manesh H.(2003) in a study entitled "Men addiction a threat against women and families" examines the consequences of men addiction in family and community. He believes that with regard to the men make up the majority of 
drug addicts, they are threat to the women's individual and family life and they are seriously harmful for the family. He considers the consequences of men addiction as follow: Individual outcomes including: physical and psychological complications and behavioral disorders, Familial consequences including: disruption and breakdown of families, disorder in couples emotional and sexual relationships, addict making of wife, prostitution of wife, violence against woman, HIV transmission, and disorder in father relationships with children, and social outcomes, including: depreciation of social and material capital, moral and social security reduction, undermining the economic, cultural and political transformation.

Farrow ${ }^{4} \&$ Brissing $^{5}$ (1990) researched over 343 teenage in the field of the relationship between family distress and drug abuse. As a result, it was found that those who pay excessive alcohol use and drug abuse were often families with troubled background.

Simons ${ }^{6} \&$ Robertson $^{7}$ (1989) in a test involving a sample of 343 male addicts and non-addicts discovered a specified mutual relationship between parent's behavioral indices, entering the children the same age deviant groups, and drug abuse. According to the study, it is important the rejecting of children by parents in children's tendency towards deviant same age groups. These researchers also believed that the rejecting of children by parents will undermine their reliability and confidence.

Based on the results of Brook ${ }^{8}$, Nomura ${ }^{9} \&$ Cohen $^{10}$ studies (1989) alcoholics topper (who drink higher than normal) and drug users often express that they have much experience of incompatibility and conflict between parents and familial inconsistencies. As well as it is related to less drug abuse by teenagers, less conflict in the family environment and appropriate parent-child relationship.

Results of the Orford ${ }^{11}$ studies (1994) about causes of addiction among students in America shows that most of the students who were addicted had structural and environmental frustrations. Ignoring their emotional needs by the community is their tendency reason to addiction.

In a research, Boyle 12 (2000) investigates existence of addiction in the family and its impact on being addict other members of the family. He believes that the older brother of addict has further effect on pushing teenagers and youth to addiction.

Also Haffman ${ }^{13}$ \& Serbon ${ }^{14}$ (2002) have discussed in their studies" the impact of parental addiction on individual tendency to addiction". Based on their findings, when parents are using drugs the children are also more likely to be addicted.

According to Pico findings (2000) emotional vacuum in children relationships with parents especially father is the cause of their tendency to addiction.

Nazrol Islam (2000) in a research entitled "sexual styles of life and social status of addicts in Bangladesh" concludes that young addicts with a high school education, have low and medium incomes and also intensity of addiction of the married men is higher than single men. He continues influence of socialize with addictive friends in individuals tendency to narcotics.

\section{Research objectives (general and special):}

The overall objective: this research project is done to achieve the following overall objective:

- analysis of narcotic addiction and provide effective strategy in awareness and prevention of it.

Specific objectives: this research project is done to achieve the following overall objective:

- recognizing the causes of narcotic tendency in Bonab.

- recognizing the frequency of the kind of narcotic in Bonab.

- recognizing the circumstances of the narcotic distribution in Bonab.

- recognizing the contamination amount of narcotic by different social class of people in Bonab.

\footnotetext{
${ }_{4}^{4}$ Farrow

${ }^{5}$ Brissing

6 Simons

${ }^{7}$ Robertson

${ }^{8}$ Brook

${ }^{9}$ Nomura

10 Cohen

11 Orford

${ }^{12}$ Boyle

${ }^{13}$ Hoffman

14 Serbon
} 
- recognizing the narcotic prevention ways in Bonab.

\section{Research questions:}

This study aims to answer the following main questions:

1. What are the main causes of narcotic tendency in Bonab?

2. What is the effective way of narcotic prevention in Bonab?

This study aims to answer the following subsidiary questions:

- What are the main important causes of narcotic tendency in Bonab?

- What kinds of narcotics are used more than others in Bonab?

- What are the narcotic distribution ways in Bonab?

- Who are the most effective people that use narcotic in Bonab?

- What are the most important ways of narcotic prevention in Bonab?

- What are the most important ways of informing the public about narcotic prevention in Bonab?

\section{Methodology of Research}

This research by taking the factor of goal into consideration is applied and field one. The population of this research consists of normal citizens, addicts quit, addicts parents, law enforcement expert, educational and cultural experts. According to Cochran formula this sample is estimated around 300 people. These populations, which are estimated randomly, are divided into 60 normal citizens, 60 addicts quit, 60 addicts' parents,and 60 law enforcement experts, 60 educational and cultural experts.

Multi variable analysis of Variance(ANOVA) is used for data analysis of statistical indicators like frequency, mean and percentage of differences in this research.Researcher's questionnaire is used for gathering data in which its variables are graded according to Likert from 5 to 1 (from the highest to lowest).

\section{Data Analysis}

\subsection{Question 1: what are the most important reasons of narcotic tendency in Bonab?}

Chart 1: the obtained mean of different ideas of people about effective reasons of narcotic tendency in Bonab

\begin{tabular}{|l|c|c|c|c|c|}
\hline \multirow{2}{*}{$\begin{array}{l}\text { Effective factors of } \\
\text { narcotic tendency }\end{array}$} & \multicolumn{4}{|c|}{ Different ideas about effective factors of narcotic } \\
\cline { 2 - 6 } & $\begin{array}{c}\text { normal } \\
\text { citizens }\end{array}$ & $\begin{array}{c}\text { Addict } \\
\text { quit }\end{array}$ & $\begin{array}{c}\text { addict's } \\
\text { parents }\end{array}$ & $\begin{array}{c}\text { law enforcement } \\
\text { expert }\end{array}$ & $\begin{array}{c}\text { cultural } \\
\text { expert }\end{array}$ \\
\hline Individual factors & 3.85 & 4.54 & 3.50 & 4.23 & 4.11 \\
\hline Environmental factors & 4.28 & 4.97 & 4.92 & 4.71 & 4.83 \\
\hline Social factors & 4.14 & 4.81 & 4.89 & 4.90 & 4.63 \\
\hline Family factors & 4 & 4.90 & 4.95 & 4.96 & 4.12 \\
\hline Economical factors & 3.28 & 4.54 & 3.58 & 4.66 & 3.99 \\
\hline
\end{tabular}

According to all of the ideas in first chart, all of the factors (individual, environmental, social, familial and economical) can be effective on narcotic tendency. The mean of all obtained scores in this chart (1. Chart) represent that almost all of the population in this study believes to the role of family and environment.

Chart 2: tests about factors that is effective in narcotic tendency among groups

\begin{tabular}{|l|c|c|c|c|c|}
\hline Source Variable & Type III sum of square & df & Mean square & Sig & PartiaL Eta squareg \\
\hline Corrected Model & & & & & \\
individual & 0.619 & 4 & 0.155 & 0.815 & $0 / 000$ \\
Cricum ferential & 0.306 & 4 & 0.076 & 0.412 & $0 / 008$ \\
Social & 0.403 & 4 & 0.101 & 0.064 & $0 / 021$ \\
Family & 0.932 & 4 & 0.233 & 0.94 & $0 / 026$ \\
Economic & 1.422 & 4 & 0.355 & 0.004 & $0 / 019$ \\
\hline
\end{tabular}




\begin{tabular}{|l|c|c|c|c|c|}
\hline Intercept & & & & & \\
individual & 81.851 & 1 & 81.851 & 0.000 & $0 / 923$ \\
Cricumderential & 112.433 & 1 & 112.433 & 0.000 & $0 / 731$ \\
Siciale & 109.231 & 1 & 109.231 & 0.000 & $0 / 282$ \\
Family & 105.157 & 1 & 105.157 & 0.000 & $0 / 380$ \\
Economic & 80.401 & 1 & 80.401 & 0.001 & $0 / 602$ \\
\hline Sort & 0.619 & 4 & 0.105 & 0.815 & $0 / 000$ \\
individual & 0.306 & 4 & 0.76 & 0.412 & $0 / 008$ \\
Cricumderential & 0.403 & 4 & 0.101 & 0.064 & $0 / 021$ \\
Social & 0.932 & 4 & 0.233 & 0.094 & $0 / 026$ \\
Family & 1.422 & 4 & 0.355 & 0.004 & $0 / 019$ \\
Economic & & & & \\
\hline Total & 82.469 & 300 & & & \\
individual & 112.739 & 300 & & & \\
Cricumderential & 109.635 & 300 & & & \\
Social & 106.089 & 300 & & & \\
Family & 81.822 & 300 & & & \\
Economic & & & & & \\
\hline Corrected Total & 0.619 & 299 & & & \\
individual & 0.306 & 299 & & & \\
Cricumderential & 0.403 & 299 & & & \\
Siciale & 0.923 & 299 & & & \\
Family & 1.422 & 299 & & & \\
Economic & &
\end{tabular}

According to second chart the meaning level (Sig) of economical factors $(0.004)$ is lower than $(0.01)$ so this mean that all of populations' idea about the role of important factors in narcotic tendency is different with each other by taking the factor of economic into consideration.

\subsection{Question 2: which kinds of narcotics have more frequency usage in Bonab?}

Chart 3: The obtained mean of different ideas about the kinds of narcotic in Bonab.

\begin{tabular}{|c|c|c|c|c|c|}
\hline \multirow{2}{*}{$\begin{array}{c}\text { Kind of } \\
\text { narcotics }\end{array}$} & \multicolumn{5}{|c|}{ Different ideas about effective factors of narcotic } \\
\cline { 2 - 6 } & $\begin{array}{c}\text { normal } \\
\text { citizens }\end{array}$ & addict quit & $\begin{array}{c}\text { addict's } \\
\text { parents }\end{array}$ & $\begin{array}{c}\text { law enforcement } \\
\text { expert }\end{array}$ & $\begin{array}{c}\text { cultural } \\
\text { expert }\end{array}$ \\
\hline Opium & 3.14 & 4.81 & 4.88 & 4.71 & 4.19 \\
\hline Heroin & 2.71 & 4.18 & 4.66 & 3.66 & 3.11 \\
\hline Hashish & 2.42 & 2.45 & 2.25 & 2.42 & 2.53 \\
\hline Crack & 3 & 1.72 & 1.16 & 1.38 & 1.81 \\
\hline Crystal & 3.42 & 4.90 & 4.89 & 4.90 & 4.33 \\
\hline
\end{tabular}

This chart shows that the usage of Opium, Heroin and Crystal is more than others and also the usage of Crack and Hashish is less than others.

Chart 4: Tests about the effects among groups in relation with the kind of narcotic used by addicts in Bonab.

\begin{tabular}{|l|c|c|c|c|c|}
\hline \multicolumn{1}{|c|}{ Source Variable } & $\begin{array}{c}\text { Type III sum of } \\
\text { square }\end{array}$ & df & $\begin{array}{c}\text { Mean } \\
\text { square }\end{array}$ & Sig & $\begin{array}{c}\text { PartiaL Eta } \\
\text { squareg }\end{array}$ \\
\hline Corrected Model & & & & & \\
Opium & 2.112 & 4 & 0.528 & 0.002 & 0.017 \\
heroeen & 2.475 & 4 & 0.619 & 0.005 & 0.019 \\
hashish & 0.042 & 4 & 0.010 & 0.932 & 0.07 \\
krak & 2.032 & 4 & 0.508 & 0.001 & 0.018 \\
Crystal & 1.667 & 4 & 0.417 & 0.087 & 0.099 \\
\hline Intercept & & & & & \\
\hline
\end{tabular}




\begin{tabular}{|l|c|c|c|c|c|}
\hline Opium & 94.439 & 1 & 94.439 & 0.000 & 0.723 \\
heroeen & 67.439 & 1 & 67.124 & 0.003 & 0.644 \\
hashish & 29.137 & 1 & 29.137 & 0.000 & 0.530 \\
krak & 16.453 & 1 & 16.453 & 0.000 & 0.487 \\
Crystal & 100.711 & 1 & 100.711 & 0.020 & 0.218 \\
\hline Sort & 2.112 & 4 & 0.528 & 0.009 & 0.017 \\
Opium & 2.475 & 4 & 0.619 & 0.005 & 0.019 \\
heroeen & 0.042 & 4 & 0.010 & 0.932 & 0.007 \\
hashish & 2.032 & 4 & 0.508 & 0.11 & 0.018 \\
krak & 1.667 & 4 & 0.417 & 0.87 & 0.099 \\
Crystal & & & & & \\
\hline Total & 96.550 & 300 & & & \\
Opium & 69.600 & 300 & & & \\
heroeen & 29.179 & 300 & & & \\
hashish & 18.484 & 300 & & & \\
krak & 102.377 & 300 & & & \\
Crystal & & & & & \\
\hline Corrected Total & 2.112 & 299 & & & \\
Opium & 2.475 & 299 & & & \\
heroeen & 0.042 & 299 & & & \\
hashish & 2.032 & 299 & & & \\
krak & 1.667 & 299 & & & \\
Crystal & & & & \\
\hline
\end{tabular}

By taking the forth chart into consideration, the meaning level (Sig) of Opium (0.002), Heroin (0.005) and Crack (0.001) is less than (0.01) so we conclude that there is differences among populations' idea about the kinds of narcotics while their ideas about other kinds are same.

\subsection{Question 3: how are the distribution ways of narcotic in Bonab?}

Chart 5: The obtained mean of different ideas about the place of narcotic distribution in Bonab.

\begin{tabular}{|c|c|c|c|c|c|}
\hline \multirow{2}{*}{$\begin{array}{c}\text { The place of narcotic } \\
\text { distribution }\end{array}$} & \multicolumn{5}{|c|}{ Different ideas } \\
\cline { 2 - 6 } & $\begin{array}{c}\text { normal } \\
\text { citizens }\end{array}$ & $\begin{array}{c}\text { addict } \\
\text { quit }\end{array}$ & $\begin{array}{c}\text { addict's } \\
\text { parents }\end{array}$ & $\begin{array}{c}\text { law enforcement } \\
\text { expert }\end{array}$ & $\begin{array}{c}\text { cultural } \\
\text { expert }\end{array}$ \\
\hline students' dormitories & 2.57 & 3.18 & 3.75 & 3 & 2.91 \\
\hline Common places \& parks & 3.14 & 4.09 & 4.16 & 3.38 & 3.06 \\
\hline House \& apartments & 3.71 & 4.45 & 4.25 & 4.09 & 4 \\
\hline shops \& markets & 3.28 & 4.10 & 3.92 & 3.28 & 3.87 \\
\hline
\end{tabular}

According to this chart, narcotics distribution in houses and apartments and parks are more than of other places among addicts in Bonab.

Chart 6: Tests about effects of the place of narcotic distribution among addicts in Bonab.

\begin{tabular}{|l|c|c|c|c|c|}
\hline Source Variable & $\begin{array}{c}\text { Type III sum } \\
\text { of square }\end{array}$ & df & $\begin{array}{c}\text { Mean } \\
\text { square }\end{array}$ & Sig & $\begin{array}{c}\text { PartiaL Eta } \\
\text { squareg }\end{array}$ \\
\hline Corrected Model & & & & & \\
students' dormitories & 0.754 & 4 & 0.189 & 0.932 & 0.001 \\
Common places \& parks & 1.100 & 4 & 0.275 & 0.005 & 0.019 \\
House \& apartments & 0.307 & 4 & 0.77 & 0.098 & 0.020 \\
shops \& markets & 0.590 & 4 & 0.147 & 0.483 & 0.017 \\
\hline Intercept & 47.494 & 1 & 47.494 & 0.000 & 0.161 \\
students' dormitories & 63.582 & 1 & 63.582 & 0.000 & 0.202 \\
Common places \& parks & 84.050 & 1 & 84.050 & 0.001 & 0.267 \\
House \& apartments & 68.081 & 1 & 68.081 & 0.000 & 0.208 \\
\hline
\end{tabular}




\begin{tabular}{|l|c|c|c|c|l|}
\hline shops \& markets & & & & & \\
\hline Sort & & & & & \\
students' dormitories & 0.754 & 4 & 0.189 & 0.932 & 0.001 \\
Common places \& parks & 1.100 & 4 & 0.275 & 0.015 & 0.019 \\
House \& apartments & 0.307 & 4 & 0.77 & 0.908 & 0.020 \\
shops \& markets & 0.590 & 4 & 0.147 & 0.483 & 0.017 \\
\hline Total & 0.000 & 300 & & & \\
students' dormitories & 0.000 & 300 & & & \\
Common places \& parks & 0.000 & 300 & & & \\
House \& apartments & 0.000 & 300 & & & \\
shops \& markets & & & & & \\
\hline Corrected Total & 48.248 & 300 & & & \\
students' dormitories & 64.681 & 300 & & & \\
Common places \& parks & 84.357 & 300 & & & \\
House \& apartments & 68.670 & 300 & & & \\
shops \& markets & & & & \\
\hline
\end{tabular}

According to the data of sixth chart the meaning level (Sig) of parks and common places (0.005) is less than (0.01) so it is concluded that people's ideas are different about the narcotic distribution in parks of Bonab. But these differences are not so important.

\subsection{Question 4: which group of social class uses narcotic more than others in Bonab?}

Chart 7: The obtained mean of different ideas about the age of addicts in Bonab.

\begin{tabular}{|c|c|c|c|c|c|}
\hline \multirow{2}{*}{ age of addicts } & \multicolumn{5}{|c|}{ Different ideas about the age of addicts } \\
\cline { 2 - 6 } & $\begin{array}{c}\text { normal } \\
\text { citizens }\end{array}$ & $\begin{array}{c}\text { addict } \\
\text { quit }\end{array}$ & $\begin{array}{c}\text { addict's } \\
\text { parents }\end{array}$ & $\begin{array}{c}\text { law enforcement } \\
\text { expert }\end{array}$ & $\begin{array}{c}\text { cultural } \\
\text { expert }\end{array}$ \\
\hline Children & 1.71 & 1.12 & 1.02 & 1.14 & 1.70 \\
\hline Teenagers & 2.71 & 4 & 4.50 & 2.80 & 2.20 \\
\hline Young people & 3.28 & 4.69 & 4.98 & 4.71 & 4.11 \\
\hline Adults & 3.28 & 3.90 & 4.93 & 4.47 & 4.08 \\
\hline Old people & 3.18 & 3.81 & 4.12 & 3.80 & 3.92 \\
\hline
\end{tabular}

According to the data of seventh chart, all ideas of the statistical population of this research about the age of addict people are same, in which all of group believe that the age of addict people is more between young and adult people in Bonab. At the other hand addicts' parents believe that it is more among teenagers and old people than others.

Chart 8: Tests about the effects of the range of addict's age in Bonab

\begin{tabular}{|l|c|c|c|c|c|}
\hline \multicolumn{1}{|c|}{ Source Variable } & $\begin{array}{c}\text { Type III sum of } \\
\text { square }\end{array}$ & df & $\begin{array}{c}\text { Mean } \\
\text { square }\end{array}$ & Sig & $\begin{array}{c}\text { PartiaL Eta } \\
\text { squareg }\end{array}$ \\
\hline Corrected Model & 0.457 & 4 & 0.114 & $0 / 092$ & $0 / 000$ \\
Children & 3.721 & 4 & 0.930 & $0 / 003$ & $0 / 008$ \\
Teenagers & 1.845 & 4 & 0.461 & $0 / 032$ & $0 / 09$ \\
Young people & 1.533 & 4 & 0.383 & $0 / 019$ & $0 / 007$ \\
Adults & 0.496 & 4 & 0.124 & $0 / 051$ & $0 / 000$ \\
Old people & & & & & \\
\hline Intercept & 8.951 & 1 & 8.951 & $0 / 000$ & $0 / 133$ \\
Children & 52.553 & 1 & 52.533 & $0 / 003$ & $0 / 280$ \\
Teenagers & 94.787 & 1 & 94.787 & $0 / 004$ & $9 / 299$ \\
Young people & 85.367 & 1 & 85.787 & $0 / 002$ & $0 / 261$ \\
Adults & 70.914 & 1 & 70.914 & $0 / 001$ & $0 / 192$ \\
Old people & \multicolumn{4}{|l}{} \\
\hline
\end{tabular}




\begin{tabular}{|l|l|l|l|l|l|}
\hline Sort & 0.457 & 4 & 0.114 & $0 / 092$ & $0 / 000$ \\
Children & 3.721 & 4 & 0.930 & $0 / 003$ & $0 / 018$ \\
Teenagers & 1.845 & 4 & 0.461 & $0 / 032$ & $0 / 009$ \\
Young people & 1.533 & 4 & 0.383 & $0 / 019$ & $0 / 007$ \\
Adults & 0.496 & 4 & 0.124 & $0 / 051$ & $0 / 000$ \\
Old people & & & & & \\
\hline Total & 300 & & & & \\
Children & 300 & & & & \\
Teenagers & 300 & & & & \\
Young people & 300 & & & & \\
Adults & 300 & & & & \\
Old people & 299 & & & & \\
\hline Corrected Total & 299 & & & & \\
Children & 299 & & & & \\
Teenagers & 299 & & & & \\
Young people & 299 & & & & \\
Adults & & & & \\
Old people & & & & \\
\hline
\end{tabular}

The data in eighth chart shows that ideas about the Teenagers of narcotic addicts are different in Bonab. So the meaning level (Sig)in this part (0.003) is less than (0.01).

\subsection{Question 5: What are the important ways of narcotic prevention in Bonab?}

Chart 9: The obtained mean of different ideas about the ways of narcotic prevention

\begin{tabular}{|l|c|c|c|c|c|}
\hline \multirow{2}{*}{ Ways of narcotic prevention } & \multicolumn{5}{|c|}{ Different ideas } \\
\cline { 2 - 6 } & $\begin{array}{c}\text { normal } \\
\text { citizens }\end{array}$ & $\begin{array}{c}\text { addict } \\
\text { quit }\end{array}$ & $\begin{array}{c}\text { addict's } \\
\text { parents }\end{array}$ & $\begin{array}{c}\text { law enforcement } \\
\text { expert }\end{array}$ & $\begin{array}{c}\text { cultural } \\
\text { expert }\end{array}$ \\
\hline Fighting with supply of narcotics & 3.71 & 4.45 & 3.83 & 4.33 & 4.12 \\
\hline Decreasing the demand of narcotics & 3.57 & 4.40 & 4.16 & 4.66 & 4.28 \\
\hline
\end{tabular}

This ninth chart shows that presenting the ways for decreasing demands can be more effective in addict prevention of Bonab.

\subsection{Question 6: What are the most important ways of informing public about narcotic prevention in Bonab?}

Chart 10: The obtained mean of different ideas about informing public in order to prevent addiction.

\begin{tabular}{|l|c|c|c|c|c|}
\hline \multirow{2}{*}{ informing ways } & \multicolumn{5}{c|}{ Different ideas } \\
\cline { 2 - 6 } & $\begin{array}{c}\text { normal } \\
\text { citizens }\end{array}$ & $\begin{array}{c}\text { addict } \\
\text { quit }\end{array}$ & $\begin{array}{c}\text { addict's } \\
\text { parents }\end{array}$ & $\begin{array}{c}\text { law enforcement } \\
\text { expert }\end{array}$ & $\begin{array}{c}\text { cultural } \\
\text { expert }\end{array}$ \\
\hline Providing cultural programs in mass media & 3.75 & 4.54 & 4.33 & 4.62 & 4.02 \\
\hline Consultation centers for addicts & 4.28 & 4.27 & 3.58 & 4.36 & 4.61 \\
\hline Changing views in institutions & 3.57 & 4.81 & 4.50 & 4.76 & 4.82 \\
\hline Informing by parents & 3.73 & 4.3 & 4.25 & 4.70 & 4.03 \\
\hline
\end{tabular}

According to tenth chart all of the above information can be effective for individual awareness about the narcotic prevention but according to citizens and addicts' parents, consultation centers can be more effective than others for narcotic prevention. From the view of addict quit, cultural and law enforcement Changing views in institutions the most effective way is for institutions.

Chart 11: Tests about the effects among groups of study about the prevention and informing ways of narcotic in Bonab

\begin{tabular}{|c|c|c|c|c|c|}
\hline Source Variable & $\begin{array}{c}\text { Type III sum of } \\
\text { square }\end{array}$ & df & $\begin{array}{c}\text { Mean } \\
\text { square }\end{array}$ & Sig & $\begin{array}{c}\text { PartiaL Eta } \\
\text { squareg }\end{array}$ \\
\hline
\end{tabular}




\begin{tabular}{|c|c|c|c|c|c|}
\hline $\begin{array}{l}\text { Corrected Model } \\
\text { Fighting with supply of narcotics } \\
\text { Decreasing the demand of narcotics } \\
\text { Providing cultural programs in mass media } \\
\text { Consultation centers for addicts } \\
\text { Changing views in institutions } \\
\text { Informing by parents }\end{array}$ & $\begin{array}{l}0.400 \\
0.656 \\
0.582 \\
0.587 \\
1.131 \\
0.527\end{array}$ & $\begin{array}{l}4 \\
4 \\
4 \\
4 \\
4 \\
4\end{array}$ & $\begin{array}{l}0.100 \\
0.164 \\
0.146 \\
0.147 \\
0.283 \\
0.132\end{array}$ & $\begin{array}{l}0.191 \\
0.202 \\
0.196 \\
0.197 \\
0.006 \\
0.185\end{array}$ & $\begin{array}{l}0.000 \\
0.008 \\
0.006 \\
0.021 \\
0.007\end{array}$ \\
\hline $\begin{array}{l}\text { Intercept } \\
\text { Fighting with supply of narcotics } \\
\text { Decreasing the demand of narcotics } \\
\text { Providing cultural programs in mass media } \\
\text { Consultation centers for addicts } \\
\text { Changing views in institutions } \\
\text { Informing by parents }\end{array}$ & $\begin{array}{c}83.559 \\
88.789 \\
89.973 \\
89.042 \\
100.890 \\
88.789 \\
\end{array}$ & $\begin{array}{l}1 \\
1 \\
1 \\
1 \\
1 \\
1\end{array}$ & $\begin{array}{c}83.559 \\
88.789 \\
89.973 \\
89.042 \\
100.890 \\
88.789 \\
\end{array}$ & $\begin{array}{l}0.000 \\
0.000 \\
0.000 \\
0.000 \\
0.002 \\
0.000\end{array}$ & $\begin{array}{l}0.821 \\
0.892 \\
0.901 \\
0.873 \\
0.928 \\
0.701\end{array}$ \\
\hline $\begin{array}{l}\text { Sort } \\
\text { Fighting with supply of narcotics } \\
\text { Decreasing the demand of narcotics } \\
\text { Providing cultural programs in mass media } \\
\text { Consultation centers for addicts } \\
\text { Changing views in institutions } \\
\text { Informing by parents }\end{array}$ & $\begin{array}{l}0.400 \\
0.656 \\
0.582 \\
0.585 \\
1.131 \\
0.527\end{array}$ & $\begin{array}{l}4 \\
4 \\
4 \\
4 \\
4 \\
4\end{array}$ & $\begin{array}{l}0.100 \\
0.164 \\
0.146 \\
0.147 \\
0.283 \\
0.132\end{array}$ & $\begin{array}{l}0.191 \\
0.202 \\
0.196 \\
0.197 \\
0.012 \\
0.185\end{array}$ & $\begin{array}{l}0.000 \\
0.008 \\
0.006 \\
0.006 \\
0.021 \\
0.007\end{array}$ \\
\hline $\begin{array}{l}\text { Total } \\
\text { Fighting with supply of narcotics } \\
\text { Decreasing the demand of narcotics } \\
\text { Providing cultural programs in mass media } \\
\text { Consultation centers for addicts } \\
\text { Changing views in institutions } \\
\text { Informing by parents }\end{array}$ & $\begin{array}{c}83.959 \\
89.441 \\
90.555 \\
89.629 \\
102.021 \\
89.316\end{array}$ & $\begin{array}{l}300 \\
300 \\
300 \\
300 \\
300 \\
300\end{array}$ & & & \\
\hline $\begin{array}{l}\text { Corrected Total } \\
\text { Fighting with supply of narcotics } \\
\text { Decreasing the demand of narcotics } \\
\text { Providing cultural programs in mass media } \\
\text { Consultation centers for addicts } \\
\text { Changing views in institutions } \\
\text { Informing by parents }\end{array}$ & $\begin{array}{l}0.400 \\
0.656 \\
0.582 \\
0.587 \\
1.131 \\
0.527\end{array}$ & $\begin{array}{l}299 \\
299 \\
299 \\
299 \\
299 \\
299\end{array}$ & & & \\
\hline
\end{tabular}

According to the data of eleventh chart, the meaning level (Sig) of Changing views in institutions by institutes $(0.006)$ is less than (0.01) so this shows that there are differences among individual's ideas.

\section{Discussion and Conclusion}

With regard to data which consists of individuals' idea in this research charts, the most effective role are for family an environment that may prepare the way for addiction in Bonab and most of the people believe that the usage of Opium, Heroin and Glass is more than Crack and Hashish. According to the findings of this research the distribution of narcotics is in houses and parks more than other places and the range of addicts' age is more among young and adult people. Finding the solutions in order to decrease demands and preventing the supply of narcotics can be effective in order to prevent addiction.Finally all the data gathered by normal citizens and addicts parents shows that the most effective role for preventing addiction is for consultation centers but the addict quit and law enforcement and cultural experts' views, teaching new ideas by institutes can be effective than others.

\section{Recommendations}

There are some suggestions here in order to prevent addiction in Bonab:

1. Providing family educational programs and making parent aware of proper manners when treating with their children, providing safe family environment against narcotics substance, proper treating with addict people and supporting them emotionally in order to help to quit their addiction. 
2. Having an effective relation with students in schools in order to making them aware of disadvantages of narcotic by law enforcement experts and educational staff.

3. Encouraging young people to avoid the wrong friendship by mass media (using episods, plays, films,...), law enforcement experts, broadcasting and department of culture.

4. Giving rewards and facilities to those addicts who give up their addiction (like: house procurement loan, employment, leisure and providing their insurance,...).

5. Establishing consultation centers and free consulting with addicts.

6. Changing the public mind about addict people (to be aware that the addict people are sick not rejected from society) and supporting those addict people in order to help them to quit their addiction.

7. Law enforcement officials' attendance in parks and common places in Bonab in order to control those places.

\section{References}

Abdi,K., (2001), Factors of Addiction Among Marginalized People, M.A. dissertation of sociology, Tehran University.

Agabakhshi, H., (2000), "The Effects of Father Addiction on Family", social journal, No. 10.

Bolhari, J., (2003), "Evaluating of Narcotics Misuse in Iranian Prisons", social journal of narcotic misuse, first year, No. 3.

Brissing, Peter, Farrow. JA (1990) a new look at gender difference in drinking and driving in flunkies experiences and attitudes among new among new adolescent drivers. Health Education \& Behavior, Vol. 17, No. 2 http:// www.elsevier .com

Gholami-e Abiz, M., (2002), "Examining Effective Social \& Economical Causes of Addiction", case study of Shiraz camp of Pirbanan", scientific journal, misused of addiction, second year, No.5.

Gidenz,A., (1994), Sociology, translated by Sabouri,M., Tehran, Ney publication.

Gorban Huseini, A., (1989), "Research on Narcotic \& Addiction", Tehran, Amirkabir.

Goreyshnezhad, R., (2000), Examining \& Comparing Addicts' Characters \& Their Attitudes Towards Narcotics with Normal People in Qazvin, second year, No. 17.

Gambari, M., (2000), Different Studies About People \& Their Attitudes Towards Narcotics, International Conference about Different Aspects of Criminal Policy towards Narcotics, Tehran.

Haj Husseini, M., Akhavan Tafti, M., (2003), "Contrasive Study of Documents Among Young Addicts \& Non-Addicts in Yazd", journal of addiction, first year, No. 3.

Hashemi, A., (2004), "A New View, The New Way In Order To Fight With Narcotics.

Rezaee, S., (2003), "Addicted Characterization", Hayat-e Sabz journal, №. 3, 36-37.

Islam,SK. Nazrul and et al (2000).« sexual life style ,Drug habit and socio- demographic status of Drug Addict in Bangladesh». Public Health, vol.114, N.5

Karampour, R., (2000), Evaluating Researches About Narcotics \& Addiction in the Treatment Centers, educational journal, second year, No.5-10.

Kosari, M., (2003), "Social Anomy \& Narcotic Addiction" Scientific journal of Narcotics Misuse, second year, No.5.

Madani, S., (2002), Family \& Addiction, journals of second Conference of Social Loss in Iran, Tehran, Agah.

Mahboubimanesh, H., (2003), "Men Addiction, Threat Against Family \& Woman", women's social \& cultural journal, sixth year, No.2.

Mobaraki, M., (2004), Examining the Relationship between Social Capital \& Crime, M.A. dissertation, Shahid Beheshti University, Tehran University.

Momtaz, F., (2002), Social Deviations, Ideas \& Views, first publication, Tehran, Enteshar Co.

Quen, B., (1994), Basics of Socialogy, translated by Tavassoli, Gh., \& Fazel, R., Tehran, Samt publication.

Sadeghi Ahari, S., (2000), "Analyzing the Cause of Returning to Addiction on Those Addicted People in Addiction Treatment Centers", addiction research journal, first year No.2.

Shahidi, M.H., (1996), Narcotics, Social Security, Rah-e Sevvom, Tehran, Ettelaat publication.

Salami, A., Davari, M., (2001), Sociology of Kajravi, Qom, University of Qom.

Salehi-e Jongani, F., (2000), "Evaluating the Social \& Economical Effects on Addiction", case study, prison of Shahr-e Kord, M.A. dissertation, Shiraz University.

Shayesteh, S., (1996), "Contastive Study of Characteristics of Addicted Young People \& Non-Addicted Young People in the Age of 1422 Years old in Isfahan", M.A. dissertation, Tarbiyat-e Modarres University.

Sotoudeh, H., (2001), Social Pathology, Tehran, Avay-e Noor. 
